\title{
A Comparison of Modern and Preindustrial Levels of Mercury in the Teeth of Beluga in the Mackenzie Delta, Northwest Territories, and Walrus at Igloolik, Nunavut, Canada
}

\author{
P.M. OUTRIDGE, ${ }^{1}$ K.A. HOBSON,${ }^{2}$ R. McNEELY ${ }^{3}$ and A. DYKE ${ }^{3}$
}

(Received 6 November 2000; accepted in revised form 25 July 2001)

\begin{abstract}
Mercury (Hg) concentrations were compared in modern and preindustrial teeth of belugas (Delphinapterus leucas) and walrus (Odobenus rosmarus rosmarus) at sites in the Canadian Arctic so that the relative amounts of natural and anthropogenic $\mathrm{Hg}$ in modern animals could be estimated. Mercury levels in the teeth of Beaufort Sea belugas captured in the Mackenzie Delta, Northwest Territories, in 1993 were significantly $(p=0.0001)$ higher than those in archeological samples dated A.D. 1450-1650. In terms of geometric means, the Hg levels in modern animals were approximately four times as high as preindustrial levels in 10-year-old belugas, rising with age to 17 times as high in 30-year-olds. Because $\mathrm{Hg}$ levels in modern teeth were highly correlated with those in soft tissues, including muscle and muktuk, which are part of traditional human diets, it is likely that soft-tissue $\mathrm{Hg}$ has increased to a similar degree over the past few centuries. The increase was not due to dietary differences over time, as shown by analysis of stable-C and - $\mathrm{N}$ isotopes in the teeth, and was unlikely to be due to sex differences or to chemical diagenesis of historical samples. Industrially related $\mathrm{Hg}$ inputs to the Arctic Ocean and Canadian Arctic Archipelago may be the most likely explanation for the increase. If so, then $80-95 \%$ of the total $\mathrm{Hg}$ in modern Beaufort Sea belugas more than 10 years old may be attributed to anthropogenic activities. In contrast, tooth $\mathrm{Hg}$ concentrations in walrus at Igloolik, Nunavut, were no higher in the 1980s and 1990s than in the period A.D. 1200-1500, indicating an absence of industrial $\mathrm{Hg}$ in the species at this location.
\end{abstract}

Key words: mercury, beluga, Delphinapterus leucas, walrus, Odobenus rosmarus, temporal trends, teeth

RÉSUMÉ. On a comparé les concentrations de mercure (Hg) dans des dents de bélugas (Delphinapterus leucas) et de morses (Odobenus rosmarus rosmarus) de notre époque et de l'ère préindustrielle, à des lieux situés dans l'Arctique canadien de façon à estimer les montants relatifs de $\mathrm{Hg}$ naturel et anthropique chez les individus contemporains. Les niveaux de mercure dans les dents de bélugas de la mer de Beaufort capturés en 1993 dans le delta du Mackenzie (Territoires du Nord-Ouest) étaient sensiblement $(p=0,0001)$ plus élevés que ceux des échantillons archéologiques remontant à une période située entre 1450 et 1650 de notre ère. En termes de moyenne géométrique, les niveaux de $\mathrm{Hg}$ chez les animaux actuels étaient près de quatre fois plus élevés que les niveaux préindustriels chez les bélugas âgés de 10 ans, augmentant avec l'âge jusqu'à être 17 fois plus élevés chez les bélugas de 30 ans. Vu que le niveau de $\mathrm{Hg}$ dans les dents actuelles était fortement corrélé à celui des tissus mous - y compris les muscles et le muktuk, qui font partie de l'alimentation humaine traditionnelle -, il est probable que la concentration de $\mathrm{Hg}$ dans les tissus mous a subi une augmentation similaire au cours des derniers siècles. Comme le montre l'analyse des isotopes de calcium stable et d'azote stable trouvés dans les dents, cette augmentation n'était pas due à des différences alimentaires au cours des années, et elle n'était probablement pas causée par la différence de sexe ou la diagenèse chimique d'échantillons historiques. L'explication la plus plausible de l'augmentation est l'apport de $\mathrm{Hg}$ industriel dans l'océan Arctique et l'archipel Arctique. Si tel est le cas, on pourrait attribuer entre 80 et 95 p. cent du $\mathrm{Hg}$ total présent chez le béluga actuel de la mer de Beaufort aux activités anthropiques. En revanche, les concentrations de $\mathrm{Hg}$ dans les dents de morses provenant d'Igloolik (Nunavut) n'étaient pas plus élevées dans les années 1980 et 1990 qu'au cours de la période située entre 1200 et 1500 apr. J.-C., signalant ainsi l'absence de Hg industriel chez cette espèce à cet endroit.

Mots clés: mercure, béluga, Delphinapterus leucas, morse, Odobenus rosmarus, tendances temporelles, dents

Traduit pour la revue Arctic par Nésida Loyer.

\section{INTRODUCTION}

Scientific focus on mercury $(\mathrm{Hg})$ in the Canadian Arctic has been increasing in recent years for several reasons.
First, people eating moderate to high amounts of traditional foods such as wild mammals and fish have higher average concentrations of $\mathrm{Hg}$ in their bodies than do southern Canadians (Health and Welfare Canada, 1979,

\footnotetext{
${ }^{1}$ Geological Survey of Canada, 601 Booth St., Ottawa, Ontario K1A 0E8, Canada and Department of Fisheries and Oceans, Central and Arctic Region, 501 University Crescent, Winnipeg, Manitoba R3T 2N6, Canada; outridge@ nrcan.gc.ca

${ }^{2}$ Canadian Wildlife Service, 115 Perimeter Road, Saskatoon, Saskatchewan S7N 0X4, Canada

${ }^{3}$ Geological Survey of Canada, 601 Booth St., Ottawa, Ontario K1A 0E8, Canada

(C) The Arctic Institute of North America
} 
1984). Second, some of these foods, including various marine mammals, contain concentrations of $\mathrm{Hg}$ that exceed Health and Welfare Canada guidelines based on average adult intake (Wagemann et al., 1996). Third, reconstructions from dated lake sediment cores indicate that, unlike the recent decreasing trend of atmospheric $\mathrm{Hg}$ deposition at southern latitudes (Engstrom and Swain, 1997), deposition rates in some (but not all) Arctic regions appear to be increasing (Hermanson, 1993, 1998; Lockhart et al., 1995, 1998; Rognerud et al., 1998). Hepatic Hg levels in Canadian belugas, narwhals, and ringed seals also displayed a significant increasing trend during the 1970s, 1980s, and 1990s (Wagemann et al., 1996). If these data are correct, the increasing trend suggests the future possibility of even higher $\mathrm{Hg}$ concentrations in biota and greater exposure for people that rely on traditional foods.

One of the weaknesses in current knowledge is uncertainty about the relative importance of natural and industrial $\mathrm{Hg}$ inputs, especially in biota. Even if $\mathrm{Hg}$ in atmospheric deposition is elevated above the natural background, it is unclear whether this loading rate is significant in comparison with the pre-existing levels of natural $\mathrm{Hg}$ in seawater and biota. Some natural geological formations may contribute substantial amounts of $\mathrm{Hg}$ to the surrounding environment (Painter et al., 1994), and the varying geographical patterns of $\mathrm{Hg}$ in some Arctic mammal species are consistent with a significant input from underlying geology (Braune et al., 1991; Wagemann et al., 1996). The distinction between natural and industrial $\mathrm{Hg}$ inputs is of crucial importance, because if the present $\mathrm{Hg}$ concentrations in biota are a natural phenomenon, then it is likely that Inuit peoples have ingested similarly high amounts of $\mathrm{Hg}$ from traditional foods for hundreds or thousands of years. Conversely, if current $\mathrm{Hg}$ levels are heavily influenced by long-range industrial pollution, then modern Inuit are experiencing higher rates of $\mathrm{Hg}$ intake from traditional foods than their predecessors did. Confirmation of recent $\mathrm{Hg}$ increases in biota could also redirect Arctic research priorities relating to environmental toxicology and chemistry.

Retrospective trend analysis of $\mathrm{Hg}$ concentrations in biota is a potentially powerful technique for determining the relative proportions of natural and anthropogenic sources in food chains. If current $\mathrm{Hg}$ levels are entirely natural, then they should be no higher than during the preindustrial period (pre-1800 A.D.). Unfortunately, soft tissues from the preindustrial era are not usually available, except in a few instances of mummification (e.g., Hansen, 1981; Wheatley and Wheatley, 1988), and thus can only rarely provide a comparison for modern $\mathrm{Hg}$ levels. The calcified remains (teeth and bones) of preindustrial mammals, on the other hand, are relatively abundant throughout the Arctic, owing to an extensive archaeological record reflecting thousands of years of human exploitation of these animals.

Recent work on laboratory animals (Eide and Wesenberg, 1993; Eide et al., 1995) and on belugas (Outridge et al., 2000a) indicates that dental Hg concentra- tions are significantly correlated either with the intake of inorganic and organic $\mathrm{Hg}$ or with soft-tissue $\mathrm{Hg}$ concentrations. In beluga, approximately half of the variance in tooth cementum $\mathrm{Hg}$ was explained by $\mathrm{Hg}$ in soft tissues, including liver, kidney, muscle, and muktuk. (The latter two tissues continue to be important traditional foods for people across the Arctic.) Thus, a comparison of $\mathrm{Hg}$ in tooth cementum samples from preindustrial and modern animals should indicate any changes in soft-tissue $\mathrm{Hg}$ over time. In this study, preindustrial and modern samples of tooth cementum from belugas in the Mackenzie Delta, Northwest Territories, and from walrus at Igloolik, Nunavut, were analyzed for $\mathrm{Hg}$. Stable-C and $-\mathrm{N}$ isotope composition was also determined in the beluga teeth to test for possible changes in diet over time, which may influence $\mathrm{Hg}$ accumulation and thus confound the comparison between time periods. Correlations between tooth $\mathrm{Hg}$ and soft-tissue $\mathrm{Hg}$, and differences in tooth $\mathrm{Hg}$ with respect to position within a jaw, were also tested for modern walrus. The concentration of other trace metals and stable $\mathrm{Pb}$ isotope ratios in the teeth of these populations were previously reported by Outridge et al. (1997).

\section{MATERIALS AND METHODS}

\section{Sample Collection, Preparation, and Ageing}

Study site locations were indicated in Outridge et al. (1997). Preindustrial beluga teeth $(\mathrm{N}=28)$ were collected from soil layers at $50-70 \mathrm{~cm}$ depth in a midden at a Classic/Late Thule site known as "Gupuk" on the eastern shore of Richards Island $\left(69^{\circ} 20^{\prime} \mathrm{N}, 134^{\circ} 30^{\prime} \mathrm{W}\right)$ in the Mackenzie River Delta. On the basis of three radiocarbon dates and associated cultural artifacts, the teeth were dated to A.D. 1450-1650 (Friesen and Arnold, 1995; C. Arnold, Prince of Wales Northern Heritage Centre, pers. comm. 1996). Beluga teeth, specifically the second and fifth right mandibular teeth, were also collected from animals harvested during the annual subsistence hunt in 1993. Those used in this study $(\mathrm{N}=25)$ were from animals landed at East Whitefish Station and Hendrickson Island, near the Gupuk site. The second tooth was used for $\mathrm{Hg}$ analysis, and the fifth for ageing purposes.

At Igloolik $\left(69^{\circ} 20^{\prime} \mathrm{N}, 81^{\circ} 48^{\prime} \mathrm{W}\right)$ in the eastern Arctic, preindustrial walrus teeth $(\mathrm{N}=11)$ were collected from Late Dorset and Classic Thule archeological features on the southeast side of Igloolik Island. These samples date from approximately A.D. 1200-1500 (M. Murray, pers. comm. 1994). Teeth were also collected from animals landed at Igloolik during subsistence hunts in 1988 $(\mathrm{N}=14)$ and $1996(\mathrm{~N}=14)$. The second right mandibular tooth from these animals was used for both $\mathrm{Hg}$ analysis and ageing. Soft-tissue $\mathrm{Hg}$ data for the walrus from 1988 were reported by Wagemann and Stewart (1994).

The preindustrial teeth at both locations were in a uniformly good state of preservation, with no evidence of 
surface erosion from post-depositional leaching or accretion of carbonates from soil porewater. Some exhibited a reddish surface staining, probably resulting from contact with iron oxides in the soil. None of these teeth were found associated with jaws, so the original position in the jaw was unknown. However, $\mathrm{Hg}$ in different teeth from several modern belugas exhibited no consistent bias related to tooth position in the jaw (Outridge et al., 2000a). Thus, while including teeth of varying jaw positions may increase the variance of preindustrial $\mathrm{Hg}$ data, it should not bias the data with respect to $\mathrm{Hg}$ in modern belugas. This question was tested for walrus in the present study. In seven animals from 1996, cementum samples were taken from all four teeth (one canine and three postcanines) on the right side of the mandibles, to test for significant differences related to tooth position in the jaw.

Both preindustrial and modern groups of teeth were sectioned vertically from root to crown with a rotary Dremel $^{\circledR}$ tool to remove a complete section of cementum, which occurs in both species as a thick, incrementally deposited outer band of material surrounding the inner core of dentine. Enamel is absent from the teeth of these species. Care was taken to include all cementum layers in the sample, and thus the $\mathrm{Hg}$ datum reported for each animal represents an integrated measure of dental $\mathrm{Hg}$ accumulated throughout life. The cementum sections were cleaned with a rotary grinder to remove dirt or adhering organic tissue from the outer surface, then immersed in $10 \% \mathrm{HNO}_{3}$ for $20 \mathrm{~s}$ and rinsed many times with distilled deionized water. The samples were air-dried at room temperature in a high-efficiency particle attenuation workbench (Model VLF-2-6-5, Microzone Corp., Nepean, Ontario). A separate section of cementum was similarly removed for stable- $\mathrm{C}$ and $-\mathrm{N}$ isotopic analysis.

Animal age was a significant variable in the dental and soft-tissue $\mathrm{Hg}$ of belugas (Outridge et al., 2000a), so any statistical comparison between time periods must be corrected for age. Anthropological investigations have suggested that modern hunters select larger and therefore older animals on average than their preindustrial counterparts did (M. Friesen, University of Toronto, pers. comm. 2000). Modern walrus and beluga teeth had previously been aged in a Department of Fisheries and Oceans laboratory by mounting in epoxy resin blocks, thin-sectioning, and enumeration of growth layers. Outridge et al. (2000a) used these ages in their study of $\mathrm{Hg}$ in modern beluga teeth and soft tissues. However, a second operator aged the preindustrial belugas for this study, and a blind test with several modern teeth found a consistent between-operator difference. Inter-operator variability is a well-known problem in age determination of marine mammals (e.g., Lawson et al., 1992). Therefore, the second operator aged the modern teeth again so that the ages of the preindustrial and modern populations used in this study would be directly comparable in methodological terms. The resulting modern ages in this study are on average $5.5 \mathrm{yr}$ lower (range of 2-12 yr lower) than those reported by Outridge et al. (2000a) for the same animals. This discrepancy was not an issue with walrus because there was no association between age and $\mathrm{Hg}$ in modern teeth (see below), so it was not necessary to age the preindustrial animals. For the modern walrus, in which the same tooth was used for both ageing and $\mathrm{Hg}$ analysis, the contact of the teeth with epoxy resin did not lead to $\mathrm{Hg}$ contamination, because laser ablation ICP-mass spectrometry analysis did not detect any $\mathrm{Hg}$ in the resin (P. Outridge, unpubl. data).

\section{Mercury Analysis}

Mercury concentrations were determined on the excised cementum sections using an AMA-254 solid sample $\mathrm{Hg}$ analyzer (Milestone Instruments, Sorisole, Italy). Mercury is thermally desorbed from solid samples, trapped on an in-line gold trap, and subsequently determined by cold-vapour atomic absorption spectrometry. An advantage of this technique is that it requires no acid predigestion of samples and so reduces contamination risk and preparation time. The instrument and the operating parameters used were described by Outridge et al. (2000a). The tooth samples reported here were analyzed in random blocks with respect to location and time period and were run concurrently with the standard reference materials (SRMs) reported by Outridge et al. (2000a). Accuracy for the SRMs was $85-101 \%$ of certified or information values, while external reproducibility was $2-4 \%$ relative standard deviation. The detection limit was $0.5 \mathrm{ng} / \mathrm{g} \mathrm{DW}$ for a $100 \mathrm{mg}$ sample weight.

\section{${ }^{13} \mathrm{C}$ and ${ }^{15} \mathrm{~N}$ Stable Isotope Analysis}

Stable carbon $\left({ }^{13} \mathrm{C} /{ }^{12} \mathrm{C}\right)$ and nitrogen $\left({ }^{15} \mathrm{~N} /{ }^{14} \mathrm{~N}\right)$ isotope analysis of tooth cementum followed the procedures described by Hobson and Sease (1998). Briefly, stable-N isotope ratios were determined on the protein fraction in cementum by loading $1 \mathrm{mg}$ powdered subsamples into tin cups and combusting at $1800^{\circ} \mathrm{C}$ in a Robo-Prep Elemental Analyzer. Stable isotope ratios were quantified using an interfaced 20:20 Europa continuous flow isotope ratio mass spectrometer (CFIRMS). Stable-C isotopes were measured by reacting powdered cementum samples with concentrated $\mathrm{H}_{3} \mathrm{PO}_{4}$; the evolved $\mathrm{CO}_{2}$ was isotopically characterized by CFIRMS. Stable isotope ratios were expressed as delta $(\delta)$ values relative to the PeeDee Belemnite or AIR standards for $\mathrm{C}$ and $\mathrm{N}$, respectively. By convention, $\delta^{13} \mathrm{C}$ values are typically negative, and $\delta^{15} \mathrm{~N}$ are positive. Analytical error was determined to be $\pm 0.3 \%$ for $\delta^{15} \mathrm{~N}$ and $\pm 0.1 \%$ o for $\delta^{13} \mathrm{C}$, using replicate measurements on albumin and calcium carbonate standards, respectively.

\section{Statistics}

Several types of statistical tests were used to evaluate whether significant changes in tooth $\mathrm{Hg}$ had occurred between time periods. First, for the walrus (in which age 
was not a significant variable for tooth $\mathrm{Hg}$ ), differences between the preindustrial, 1988, and 1996 samples were tested with a one-way analysis of variance. Subsequently, the two modern samples were combined and the preindustrial-modern comparison was tested with a t-test. For beluga data, in which age was a significant variable in tooth $\mathrm{Hg}$, two different tests were employed. First, assuming that the tooth $\mathrm{Hg}$-age relationship was the same for preindustrial and modern animals, the difference in mean values between preindustrial and modern populations was tested with a one-way analysis of co-variance, with age as the co-variate and time period as the main effect. Alternatively, assuming that the tooth $\mathrm{Hg}$-age relationship was not the same, a linear regression model was estimated for tooth $\mathrm{Hg}$ and age for the preindustrial sample. The modern samples were then compared to the $95 \%$ confidence intervals for this model. Modern tooth $\mathrm{Hg}$ concentrations that fell outside the $95 \%$ limits were significantly different from those in the preindustrial population at $p<0.05$. Mercury concentration data were $\log _{n}$ transformed, while counts of age were square-root transformed (Sokal and Rohlf, 1981) prior to regression analysis; however, both the transformed and untransformed data sets satisfied the assumptions of normality and homoscedasticity. The transformed data models are presented below. Stable isotope data were $\log _{\mathrm{n}}$ transformed, and differences between preindustrial and 1993 samples tested with a t-test.

\section{RESULTS}

\section{Tooth Hg in Walrus}

Analysis of all four teeth from the mandibles of seven walrus found no significant differences or consistent trends with respect to position in the jaw (Table 1). Across all animals, tooth $\mathrm{Hg}$ was not correlated with age (ANOVA df $=22, \mathrm{r}^{2}=0.09, p=0.16$ ); nor was it correlated with liver and kidney $\mathrm{Hg}$ concentrations in walrus from 1988 (kidney data: ANOVA $\mathrm{df}=11, \mathrm{r}^{2}=$ $0.02, p=0.70$; liver data: ANOVA df $=12, \mathrm{r}^{2}=0.00, p=$ $0.83)$. There were no significant differences in dental $\mathrm{Hg}$ between the two modern collection years (1988 and 1996), or between preindustrial teeth and the combined modern teeth (Fig. 1).

\section{Tooth Hg in Beluga}

Mercury concentrations in modern beluga teeth were on average almost 20 times as high as those in preindustrial specimens, although the variability in modern animals was also relatively large. Arithmetic mean $( \pm \mathrm{SD})$ values were $98.4 \pm 109 \mathrm{ng} / \mathrm{g}$ DW for modern samples and $5.0 \pm 4.0$ $\mathrm{ng} / \mathrm{g}$ DW for preindustrial samples, with median values of 55.4 and $3.6 \mathrm{ng} / \mathrm{g} \mathrm{DW}$, respectively. One-way analysis of co-variance (with animal age as co-variate) indicated that modern animals contained significantly more tooth $\mathrm{Hg}$ than preindustrial belugas $(\mathrm{df}=48, \mathrm{~F}=23.87, p=0.000029)$. Regression analysis of tooth $\mathrm{Hg}$ versus age for both time periods found significant $(p<0.01)$ differences between regression slopes (slope co-efficients given as $\pm \mathrm{SE}$; Modern: $\log _{\mathrm{n}}$ [tooth $\left.\mathrm{Hg}\right]=(1.29 \pm 0.27) \cdot \sqrt{ }$ Age -2.14 ; Preindustrial: $\log _{\mathrm{n}}$ [tooth $\left.\mathrm{Hg}\right]=(0.52 \pm 0.13) \cdot \sqrt{ }$ Age -0.05$)$. Comparison of the modern belugas with the $95 \%$ confidence intervals for the preindustrial population showed that, on an age-adjusted basis, 18 out of 25 animals had significantly higher tooth $\mathrm{Hg}$ than would be predicted from the preindustrial sample (Fig. 2). In the majority of these 18 cases, the modern $\mathrm{Hg}$ levels were more than 20 times the upper 95 th percentile for preindustrial belugas of comparable age. One preindustrial animal aged $27 \mathrm{yr}$ was considerably older than most of the population. This disparity in age might have unduly influenced the preindustrial regression; however, recalculation of the equation after eliminating that individual gave a similar regression $\left(\log _{\mathrm{n}}\right.$ [tooth $\left.\mathrm{Hg}\right]=(0.44 \pm 0.16) \cdot \sqrt{ }$ Age +0.16$)$, and hence the individual was included in the analysis.

The regressions of tooth $\mathrm{Hg}$ against age were used to calculate geometric mean estimates of tooth $\mathrm{Hg}$ for modern and preindustrial belugas of given ages (Fig. 3). The difference in geometric mean $\mathrm{Hg}$ between modern and preindustrial animals increased exponentially with age, from 4.1 times as high as preindustrial levels in 10-yearolds to 16.7 times as high in 30 -year-olds.

\section{${ }^{13} \mathrm{C}$ and ${ }^{15} \mathrm{~N}$ Stable Isotopes in Beluga Teeth}

There was a significant $(p<0.001)$ difference in mean $\delta^{13} \mathrm{C}$ between modern and preindustrial belugas, with values of $-15.0 \pm 0.5 \%$ and $-13.8 \pm 0.8 \%$, respectively. In contrast, $\delta^{15} \mathrm{~N}$ values were virtually identical between the two groups $(19.9 \pm 0.6 \%$ and $19.8 \pm 0.3 \%$ o, respectively $)$. Tooth $\mathrm{Hg}$ concentrations were not significantly correlated with $\delta^{13} \mathrm{C}$ values in either the modern or the preindustrial population (Fig. 4a). Tooth $\mathrm{Hg}$ was significantly correlated with $\delta^{15} \mathrm{~N}$ values in modern beluga $\left(\mathrm{r}^{2}=0.47, \mathrm{~F}=19.4, p<0.001\right)$, but not in preindustrial animals (Fig. 4b).

\section{DISCUSSION}

Our results indicate that Beaufort Sea belugas captured in the Mackenzie Delta experienced a significant increase in tooth $\mathrm{Hg}$ between A.D. 1450-1650 and 1993. The timing of the increase is unknown because of the absence of other samples from within this ca. $450 \mathrm{yr}$ interval. The increase was age-dependent. Modern 10-year-old animals had geometric mean $\mathrm{Hg}$ four times as high as that in preindustrial animals, but this increased to eight times as high in 20-year-olds and almost 17 times as high in 30year-olds. Because tooth $\mathrm{Hg}$ is significantly correlated with $\mathrm{Hg}$ in soft tissue (Outridge et al., 2000a), soft-tissue $\mathrm{Hg}$ concentrations probably increased to a similar degree. 
TABLE 1. Mercury concentrations (ng/g DW) in teeth from different positions in the mandibles of walrus. (Canine and postcanines 1-3 are positioned from front to back of the jaw, respectively.)

\begin{tabular}{lccccc}
\hline \hline & & \multicolumn{5}{c}{ Tooth Type } \\
\cline { 3 - 6 } Walrus ID & Age (yr) & Canine & Postcanine 1 & Postcanine 2 & Postcanine 3 \\
\hline IG96-01 & 17 & 1.6 & 1.7 & 1.8 & 1.1 \\
IG96-20 & 16 & 0.6 & $<0.5$ & 0.7 & 1.0 \\
IG96-22 & 13 & 0.7 & 0.6 & 0.9 & 2.0 \\
IG96-23 & 26 & 4.6 & 1.6 & 0.9 & 1.6 \\
IG96-26 & 28 & 0.7 & 0.7 & 1.3 & 4.0 \\
IG96-36 & 22 & 1.9 & 0.7 & 0.8 & 0.6 \\
IG96-38 & 19 & 0.8 & 0.6 & 0.6 & 0.7 \\
Mean \pm SD & & $1.6 \pm 1.4$ & $0.8 \pm 0.6$ & $1.0 \pm 0.4$ & $1.5 \pm 1.2$ \\
\hline \hline
\end{tabular}

Since mercury both bioaccumulates with animal age and biomagnifies through food webs (Friberg et al., 1979), a relatively small increase in environmental $\mathrm{Hg}$ concentrations or bioavailability over time could produce large and age-dependent increases in animals at the upper levels of marine food chains (Bernhard and Andreae, 1984), such as those observed here in beluga.

The average modern $\mathrm{Hg}$ concentrations in the Mackenzie Delta beluga were $1.34 \pm 0.67 \mu \mathrm{g} / \mathrm{g}$ wet weight in muscle and $0.78 \pm 0.41 \mu \mathrm{g} / \mathrm{g}$ in muktuk (Wagemann et al., 1996). Both are above the Canadian $\mathrm{Hg}$ guideline of 0.5 $\mu \mathrm{g} / \mathrm{g}$ wet weight for human consumption of fish flesh (Health and Welfare Canada, 1979). Given the relative elevation of tooth $\mathrm{Hg}$ in modern animals and the linear relationships between tooth and soft-tissue concentrations, it is likely that preindustrial animals had muscle and muktuk Hg levels that were well below the guideline value. The implication is that modern Inuit in the Delta who consume about the same amount of beluga muscle and muktuk as their preindustrial forebears would ingest on average almost 10 times as much $\mathrm{Hg}$ from this source, particularly given their hunting preference for larger and therefore older animals (M. Friesen, pers. comm. 2000).

There is evidence from archived soft tissues that some of the increase occurred recently and, therefore, that $\mathrm{Hg}$ levels in Mackenzie Delta belugas may still be increasing. Between the early 1980s and the 1990s, a significant increase of liver $\mathrm{Hg}$ in age-adjusted terms occurred in both the Beaufort Sea beluga and various eastern Arctic populations (Wagemann et al., 1996). The average increase for 30-year-old animals in the Delta was approximately $60 \%$ between $1983-84$ and 1993, compared to $1670 \%$ over the preceding $450 \mathrm{yr}$ (based on the tooth data). Upward trends of $\mathrm{Hg}$ have also been reported in other marine biota and humans of the Arctic over various time spans. Using marine bivalve shells as proxy indicators of seawater Hg concentrations, Outridge et al. (2000b) found a recent significant increase of $\mathrm{Hg}$ to twice average Holocene levels at a site in southern Hudson Bay, but not at higher-latitude sites in the central Canadian Arctic. A significant increase of 43-65\% was observed between 1975 and 1998 in the $\mathrm{Hg}$ content of eggs of thick-billed

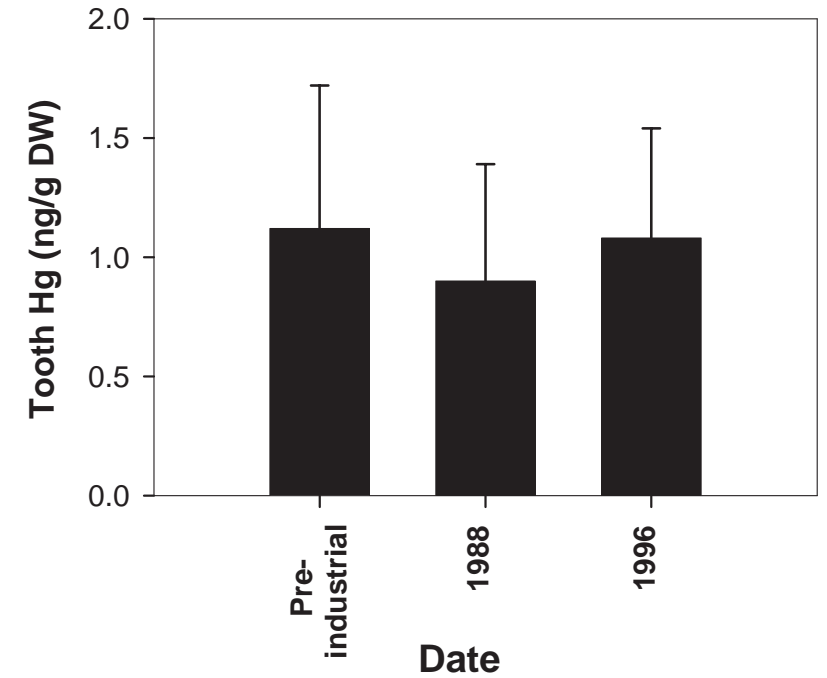

FIG. 1. Walrus tooth $\mathrm{Hg}$ concentrations (mean $\pm \mathrm{SD} n g / g \mathrm{DW}$ ) for preindustrial and modern samples at Igloolik.

murres (Uria lomvia) and northern fulmars (Fulmarus glacialis) in Lancaster Sound in the central High Arctic (Braune et al., 2001). Ringed seals (Phoca hispida) in the western Arctic surveyed in the early 1990s accumulated liver $\mathrm{Hg}$ on an age-related basis at approximately three times the rate of seals at the same location in the 1970 s (Wagemann et al., 1996). The hair of modern humans in Greenland showed significant increases: Hg concentrations were 2.5 times as high as those in mummified samples from the 15th century (Hansen, 1981). Similarly, Wheatley and Wheatley (1988) reported that $\mathrm{Hg}$ in the hair of modern humans and polar bears (Ursus maritimus) at different sites in the Canadian Arctic was at least several times higher than in preindustrial samples. Unfortunately, age may be a confounding factor in the latter comparisons involving hair, because the preindustrial individuals were not aged.

In contrast to the findings for Mackenzie Delta belugas, modern Igloolik walrus did not exhibit increased dental $\mathrm{Hg}$ concentrations compared to their preindustrial counterparts. This species also did not exhibit significant relationships between tooth and soft-tissue $\mathrm{Hg}$. Thus, while tooth $\mathrm{Hg}$ in walrus may be a poor biomonitor of tissue $\mathrm{Hg}$, there was no evidence of industrial $\mathrm{Hg}$ inputs in this species at this location. It is possible that walrus may not be reliable indicators of any increases of $\mathrm{Hg}$ in the marine ecosystem. Biomagnification of $\mathrm{Hg}$ is likely to be less pronounced in the short, detritus-based walrus food chain than in those of higher-order consumer species such as belugas or seals. Walrus feed predominantly on molluscs, which generally contain less than $0.05 \mu \mathrm{g} / \mathrm{g} \mathrm{Hg}$ (Wagemann and Stewart, 1994). Hg levels in walrus tissues are only 1$2 \%$ of those in beluga and seal tissues, and thus well below the guideline value of $0.5 \mu \mathrm{g} / \mathrm{g}$ wet weight (Wagemann and Stewart, 1994; cf. Wagemann et al., 1996). 


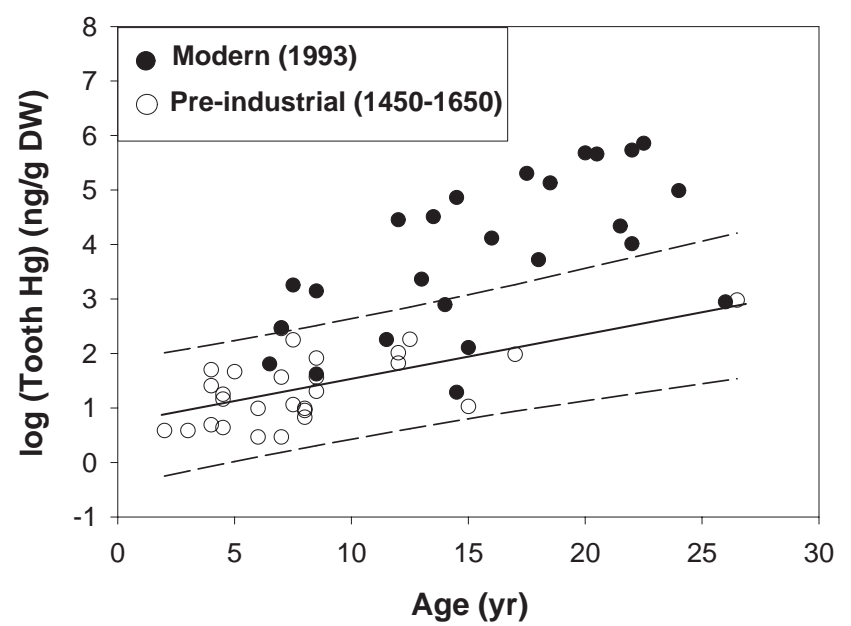

FIG. 2. Beluga tooth $\mathrm{Hg}$ concentrations as a function of age for modern and preindustrial samples from the Mackenzie Delta. (To simplify the plot, we show the untransformed age data. The solid line represents the regression equation: $\log _{n}($ tooth $\mathrm{Hg})=0.08 \pm 0.02 \bullet$ age +0.72 , for the preindustrial animals. The dashed lines represent the $95 \%$ confidence limits for this regression. Modern tooth $\mathrm{Hg}$ concentrations that fall above the upper $95 \%$ confidence limit are significantly different than those in the preindustrial population at $p<0.05$. Identical conclusions result whether transformed or untransformed ages are used.)

\section{Could the Hg Increase in Belugas be a Chemical or Biological Artifact?}

The temporal comparison of $\mathrm{Hg}$ levels in belugas could theoretically be confounded by a number of factors apart from age. These include chemical diagenesis (alteration) of the preindustrial teeth while they were buried; changing dietary preferences of belugas through time, which could expose modern animals to higher $\mathrm{Hg}$ concentrations in their prey; and sex-ratio differences between the harvested modern and preindustrial animals. Each factor is evaluated below to determine its likelihood and possible effect on the results.

Sex ratios could differ between the historical and modern beluga harvests because the modern hunters' preference for larger animals tends to bias their selection towards males. However, gender did not significantly influence soft-tissue Hg levels either in the Mackenzie Delta beluga (on an age-adjusted basis; see Outridge et al., 2000a: Fig. 2), or in eastern Arctic beluga and a number of other marine mammals (Wagemann et al., 1995).

Exposure of belugas to different levels of dietary $\mathrm{Hg}$ may have occurred as prey availability or selection varied through time. However, the lack of change in mean $\delta^{15} \mathrm{~N}$ values in beluga tooth cementum indicates an overall similarity between the trophic status of the modern and preindustrial populations (see review by Michener and Schell, 1994). The only isotopic parameter correlated with tooth $\mathrm{Hg}$ levels in either the modern or the preindustrial population was $\delta^{15} \mathrm{~N}$.

Although a significant difference in $\delta^{13} \mathrm{C}$ values was found (modern beluga being 1.2\%o lower on average than preindustrial animals), this change may be related to

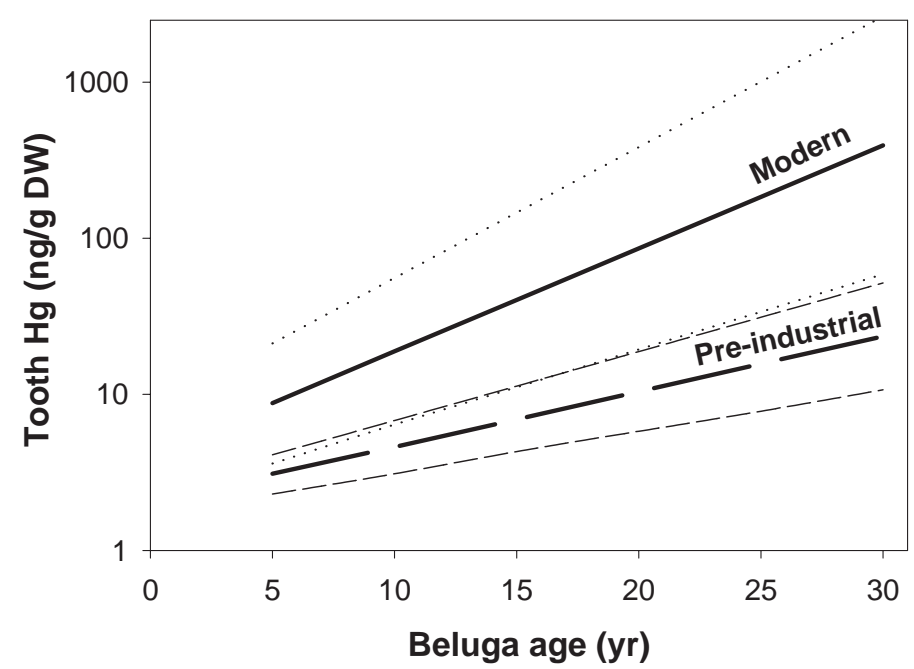

FIG. 3. Estimates of geometric mean tooth $\mathrm{Hg}$ concentrations for modern and preindustrial Mackenzie Delta belugas. (Lines representing means are labelled; dashed (preindustrial) or dotted (modern) lines indicate \pm SE of these estimates. The geometric means are based on the regressions of tooth $\mathrm{Hg}$ versus untransformed age equations; see Fig. 2.)

changing ocean temperatures or declining marine ecosystem productivity rather than to dietary changes. Schell (2000), who reported that $\delta^{13} \mathrm{C}$ values in the baleen plates of Bering Sea bowhead whales (Balaena mysticetus) in the early 1990 s were about $2.5 \%$ o lower than in the pre- 1900 period, ascribed the change to declining marine productivity. $\delta^{15} \mathrm{~N}$ values did not change during this time.

There is currently no definitive test to determine whether and to what extent diagenesis has altered the chemical composition of historical buried teeth and bones. Diagenesis could take one of two forms: exchange of dissolved $\mathrm{Hg}$ with groundwater (through adsorption or leaching), and volatilization of $\mathrm{Hg}$ from exposed and buried teeth. Accumulation of $\mathrm{Hg}$ from groundwater or soil porewater would tend to increase the risk of a Type II ("false negative") error by increasing $\mathrm{Hg}$ concentrations in preindustrial teeth. At worst, therefore, this type of diagenesis would lead to an underestimate of the degree of the modern increase. Leaching of $\mathrm{Hg}$ could also occur under some conditions and would increase the possibility of a Type I ("false positive") result. However, the acidic porewaters required for this process to occur would also erode the apatite matrix itself, resulting in visible damage and eventually the complete dissolution of the teeth. The absence of visible deterioration on the surfaces of the samples in this study suggests that leaching or adsorption of $\mathrm{Hg}$ probably did not occur.

Volatilization of some forms of $\mathrm{Hg}$, especially elemental $\mathrm{Hg}$, may occur if temperatures are sufficiently high. However, temperature profiles from drilled boreholes at several locations on the eastern shore of Richards Island near Gupuk indicated that air and ground temperatures for most of each year were well below freezing (Burgess and Smith, 2000; M. Nixon, Geological Survey of Canada, pers. comm. 2001). Even with the recent global warming 

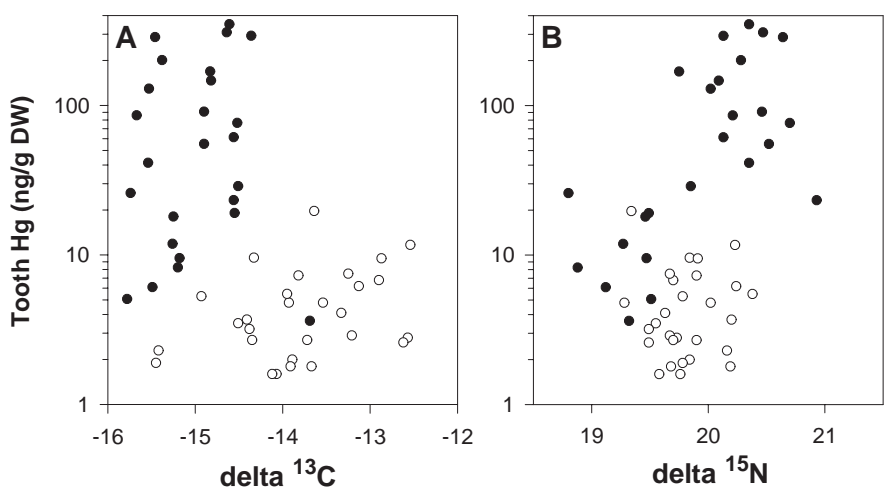

FIG. 4. Tooth $\mathrm{Hg}$ as a function of stable $\delta^{13} \mathrm{C}$ and $\delta^{15} \mathrm{~N}$ values of modern and preindustrial beluga tooth cementum. Units for stable-C and $-\mathrm{N}$ isotopes are \%o. Black dots indicate modern samples and white dots, preindustrial samples.

trend, mean annual ground surface temperatures at these sites in the early to mid 1990 s ranged from $-4^{\circ}$ to $-8^{\circ} \mathrm{C}$, with brief summer maxima lower than $9^{\circ} \mathrm{C}$. The teeth were recovered from depths of $50-70 \mathrm{~cm}$. At $50 \mathrm{~cm}$ depth in the boreholes, in soils and terrain similar to those at the Gupuk site, temperatures were uniformly colder than at the surface and were at most only slightly above freezing in summer. The maximum summer thaw depths ranged from about 50 to $80 \mathrm{~cm}$, depending on the site (Nixon, 2000). By comparison, even elemental $\mathrm{Hg}$, the most volatile $\mathrm{Hg}$ species, does not exhibit significant volatility in soils and sediments at temperatures below $40^{\circ} \mathrm{C}$, while binding of $\mathrm{Hg}$ to various organic and inorganic ligands increases the effective volatilization temperature to over $100^{\circ} \mathrm{C}$ (Azzaria and Aftabi, 1991; Biester and Scholz, 1997). This comparison suggests that volatilization is unlikely to have occurred under the site conditions prevailing at Gupuk. The form of $\mathrm{Hg}$ predominating in teeth is also a factor in this consideration. It is unlikely that elemental $\mathrm{Hg}$ or other unbound $\mathrm{Hg}$ species occur in teeth. Although $\mathrm{Hg}$ speciation in teeth is poorly known, Eide et al. (1994) showed that $\mathrm{Hg}$ was present in the organic (i.e., proteinaceous) fraction of rodent teeth. Metals are deposited in teeth from the bloodstream into a protein-rich cellular matrix on the outer formative edge of the tooth (Hillson, 1986). Blood $\mathrm{Hg}$ in belugas is predominantly methyl-Hg (Hyatt et al., 1999), which binds to proteins, raising the possibility that this may be the predominant $\mathrm{Hg}$ form in teeth.

Another argument against diagenesis is that it would tend to obscure a significant tooth $\mathrm{Hg}$-age relationship and increase data variance, because the degree of diagenesis among individual teeth should vary as a result of the twocentury span during which they were deposited on site. In fact, however, the preindustrial sample exhibited a significant tooth $\mathrm{Hg}$-age relationship and lower variance than the modern data.

In summary, therefore, there is no evidence that chemical and biological artifacts may have significantly affected $\mathrm{Hg}$ levels in the preindustrial teeth during post-deposition burial, or otherwise confounded the modern-preindustrial comparison.

\section{Is the Hg Increase in Beluga Natural or Anthropogenic?}

Irrespective of whether the long-term increase in beluga $\mathrm{Hg}$ is a natural phenomenon or is related to anthropogenic activities, it represents a significant elevation of beluga $\mathrm{Hg}$ body burdens. However, several lines of evidence suggest that industrial $\mathrm{Hg}$ contamination may be the cause. Recent $\mathrm{Hg}$ deposition rates along the northern Siberian coast, including Wrangel Island off northeastern Siberia, are possibly $50-100 \%$ higher than in preindustrial times and are correlated with recent increases in $\mathrm{Pb}$ deposition (Rognerud et al., 1998). Kara Sea sediments, for example, are heavily contaminated with $\mathrm{Hg}$ that may be traced back to emissions and effluents from Russian/Eurasian industry and fossil fuel burning (Siegel et al., 2001). The Canadian Arctic Archipelago and Arctic Ocean are similarly influenced by atmospheric and oceanic circulation patterns that promote the eastward transport of airborne and waterborne pollution ultimately from western Siberia (Kola Peninsula, Norilsk), the Urals, and other Russian and central European industrial areas (Barrie et al., 1992; Macdonald et al., 2000). The eastward transport of Eurasian pollutants into the Canadian Arctic is indicated by $\mathrm{Pb}$ isotope studies of atmospheric particulates (Sturges et al., 1993), Beaufort Sea belugas (Outridge et al., 1997), and Hudson Bay lake sediments (Outridge et al., in press). If Eurasian $\mathrm{Pb}$ and $\mathrm{Hg}$ are present in atmospheric deposition over the Canadian Arctic, and Eurasian $\mathrm{Pb}$ is present in Beaufort Sea belugas, then Eurasian industrial $\mathrm{Hg}$ is a plausible source for the recent $\mathrm{Hg}$ increase in the animals. Another possible source of elevated $\mathrm{Hg}$ in the Arctic Ocean may be mining of the numerous placer gold and cinnibar $(\mathrm{HgS})$ deposits found in the northern Siberian coastal plain (USSR, 1967). Such mining is thought to have commenced during the Stalinist gulag era (Conquest, 1979).

If the $\mathrm{Hg}$ increase in the beluga was unrelated to human activities, then a natural mechanism that could significantly increase $\mathrm{Hg}$ inputs or bioavailability over the span of 500 years must be invoked. A significant range expansion of the Beaufort Sea beluga might have exposed modern animals to regionally higher natural $\mathrm{Hg}$ levels. However, there is no evidence of a range expansion over the past century (such as reports of belugas now being hunted in areas of the Queen Elizabeth Islands where they were historically absent). Some other possible mechanisms could include increased dust deposition, volatile biogenic emissions, or tectonic activity (see Nriagu, 1989). In this sparsely vegetated landscape, which shows no evidence of recently increased geological activity, such hypotheses are less empirically supportable than that of an anthropogenic source.

The belugas probably acquire most of their elevated $\mathrm{Hg}$ burden from the Beaufort Sea and Arctic Ocean, rather than in the Mackenzie Delta. Current $\mathrm{Hg}$ deposition rates in the Delta and on the northern Alaskan coastal plain appear to be virtually identical to those of the preindustrial period (Landers et al., 1995; Allen-Gil et al., 1997; Lockhart 
et al., 1998). This is probably because of the strong influence of relatively clean North Pacific air masses on this region, in contrast to the Queen Elizabeth Islands and Arctic Ocean. In addition, belugas harvested in the Mackenzie Delta actually spend most of each year out in the Beaufort Sea and the Queen Elizabeth Islands (Wagemann et al., 1996; DFO, 2000), and they have been tracked as far west as Wrangel Island (P. Richard, Dept. of Fisheries and Oceans, pers. comm. 2001).

In conclusion, there is little evidence for the suggestion that the large $\mathrm{Hg}$ increase in modern belugas could be due to chemical or biological artifacts, or to a natural phenomenon. The simplest explanation that matches all of the facts to date is increased industrial $\mathrm{Hg}$ inputs to the Arctic Ocean or Canadian Archipelago, possibly from Eurasia, as indicated by $\mathrm{Pb}$ isotope tracing and meteorological/oceanographic considerations. If this conclusion is correct, then $80-95 \%$ of the $\mathrm{Hg}$ in modern Beaufort Sea belugas over 10 years of age is attributable to anthropogenic sources.

Future work using this approach to discriminate natural and industrial $\mathrm{Hg}$ should focus on long-lived piscivorous and carnivorous marine species, such as seals, narwhal, and polar bears, as well as on belugas, which may be relatively susceptible to small $\mathrm{Hg}$ increases in seawater because of the processes of bioaccumulation and biomagnification. Because of geographic variations in geological background $\mathrm{Hg}$ levels, and possibly in anthropogenic inputs, these studies will have to be conducted on a site-specific basis.

\section{ACKNOWLEDGEMENTS}

Thanks are due to the archeologists and museum curators who excavated the preindustrial teeth and kindly made them available for this project, together with the necessary background information: Max Friesen, Jim Savelle, Darlene Balkwill, and Chuck Arnold for the Gupuk beluga samples, and Maribeth Murray for the Igloolik walrus. Modern teeth were loaned by the Fisheries Joint Management Committee of Nunavut, through the offices of Rob Stewart, Department of Fisheries and Oceans, Winnipeg. Mark Nixon and Larry Dyke of the GSC kindly provided information on borehole temperature profiles. Miriam Wygergangs operated the Milestone Analyzer, while Linda Cataldo provided other technical assistance. Barb Stewart of Sila Consultants carried out the ageing work reported in this study. Stable isotope analyses were performed at the Department of Soil Science, University of California (Davis) by David Harris, with preparatory work by Pat Healy. The work was supported financially by the Metals in the Environment Research Network (Canada), the Canadian Wildlife Service, and the Geological Survey of Canada.

\section{REFERENCES}

ALLEN-GIL, S.M., GUBALA, C.P., LANDERS, D.H., LASORSA, B.K., CRECELIUS, E.A., and CURTIS, L.R. 1997. Heavy metal accumulation in sediment and freshwater fish in U.S. Arctic lakes. Environmental Toxicology and Chemistry 16: $733-741$.

AZZARIA, L.M., and AFTABI, A. 1991. Stepwise thermal analysis technique for estimating mercury phases in soils and sediments. Water, Air and Soil Pollution 56:203-217.

BARRIE, L.A., GREGOR, D., HARGRAVE, B., LAKE, R., MUIR, D., SHEARER, R., TRACEY, B., and BIDLEMAN, T. 1992. Arctic contaminants: Sources, occurrence and pathways. The Science of the Total Environment 122:1-74.

BERNHARD, M., and ANDREAE, M.O. 1984. Transport of trace metals in marine food chains. In: Nriagu, J.O., ed. Changing metal cycles and human health. New York: Springer-Verlag. $143-167$.

BIESTER, H., and SCHOLZ, C. 1997. Determination of mercury binding forms in contaminated soils: Mercury pyrolysis versus sequential extractions. Environmental Science and Technology $31: 233-239$.

BRAUNE, B.M., NORSTROM, R.J., WONG, M.P., COLLINS, B.T., and LEE, J. 1991. Geographical distribution of metals in livers of polar bears from the Northwest Territories, Canada. The Science of the Total Environment 100:283-299.

BRAUNE, B.M., DONALDSON, G.M., and HOBSON, K.A. 2001. Contaminant residues in seabird eggs from the Canadian Arctic. I. Temporal trends 1975-1998. Environmental Pollution 114: $39-54$.

BURGESS, M.M., and SMITH, S.L. 2000. Shallow ground temperatures. In: Dyke, L.D., and Brooks, G.R., eds. The physical environment of the Mackenzie Valley, Northwest Territories: A base line for the assessment of environmental change. Geological Survey of Canada Bulletin 547. 89-103.

CONQUEST, R. 1979. Kolyma: The Arctic death camps. Oxford: Oxford University Press. 256 p.

DFO (DEPARTMENT OF FISHERIES AND OCEANS). 2000. Eastern Beaufort Sea beluga. DFO Science Stock Status Report E5-38 (2000). 15 p.

EIDE, R., and WESENBERG, G.R. 1993. Mercury contents of indicators and target organs in rats after long-term, low-level, mercury vapor exposure. Environmental Research 61: $212-222$.

EIDE, R., SCHIØNNING, J.D., BJUGN, R., WESENBERG, G.R., and FOSSE, G. 1994. Autometallographic demonstration of mercury in rat molars. Scandinavian Journal of Dental Research 102:76-80.

EIDE, R., SCHIØNNING, J.D., ERNST, E., HANSEN, I.M., and WESENBERG, G.R. 1995. Mercury content in rat teeth after administration of organic and inorganic mercury: The effects of interrupted exposure and of selenite. Acta Odontologica Scandinavica 53:12-16.

ENGSTROM, D.R., and SWAIN, E.B. 1997. Recent declines in atmospheric mercury deposition in the upper Midwest. Environmental Science and Technology 31:960-967. 
FRIBERG, L., NORDBERG, G.F., and VOUK, V., eds. 1979. Handbook on the toxicology of metals. Amsterdam: Elsevier/ North-Holland Press.

FRIESEN, T.M., and ARNOLD, C.D. 1995. Zooarchaeology of a focal resource: Dietary importance of beluga whales to the precontact Mackenzie Inuit. Arctic 48:22-30.

HANSEN, J.C. 1981. Trace metal concentrations in hair from ancient and present-day Greenlanders. Arctic Medical Research 33:543-545.

HEALTH AND WELFARE CANADA. 1979. Methylmercury in Canada: Exposure of Indian and Inuit residents to methylmercury in the Canadian environment. Ottawa: Medical Services Branch.

. 1984. Methylmercury in Canada: Exposure of Indian and Inuit residents to methylmercury in the Canadian environment. Ottawa: Medical Services Branch.

HERMANSON, M.H. 1993. Historical accumulation of atmospherically derived pollutant trace metals in the Arctic as measured in dated sediment cores. Water, Science and Technology 28:33-41.

- 1998. Anthropogenic mercury deposition to Arctic lake sediments. Water, Air and Soil Pollution 101:309-321.

HILLSON, S. 1986. Teeth. Cambridge: Cambridge University Press.

HOBSON, K.A., and SEASE, J.L. 1998. Stable isotope analyses of tooth annuli reveal temporal dietary records: An example using Stellar sea lions. Marine Mammal Science 14:116-129.

HYATT, C.K., TREBACZ, E., METNER, D.A., WAGEMANN, R., FRIESEN, S., and LOCKHART, W.L. 1990. Mercury and selenium in the blood and tissues of beluga whales from the western Canadian Arctic. Poster and abstract. Proceedings of the International Conference on Mercury in the Environment, Rio de Janeiro, Brazil, May 1999.

LANDERS, D.H., FORD, J., GUBALA, C., MONETTI, M., LASORSA, B.K., and MARTINSON, J. 1995. Mercury in vegetation and lake sediments from the U.S. Arctic. Water, Air and Soil Pollution 80:591-601.

LAWSON, J.W., HARRISON, G.D., and BOWEN, W.D. 1992. Factors affecting accuracy of age determinations in the harp seal, Phoca groenlandica. Marine Mammal Science 8: 169-171.

LOCKHART, W.L., WILKINSON, P., BILLECK, B.N., HUNT, R.V., WAGEMANN, R., and BRUNSKILL, G.J. 1995. Current and historical inputs of mercury to high-latitude lakes in Canada and to Hudson Bay. Water, Air and Soil Pollution 80:603-610.

LOCKHART, W.L., WILKINSON, P., BILLECK, B.N., DANELL, R.A., HUNT, R.V., BRUNSKILL, G.J., DELARONDE, J., and ST. LOUIS, V. 1998. Fluxes of mercury to lake sediments in central and northern Canada inferred from dated sediment cores. Biogeochemistry 40:163-173.

MACDONALD, R.W., BARRIE, L.A., BIDLEMAN, T.F., DIAMOND, M.L., GREGOR, D.J., SEMKIN, R.G., STRACHAN, W.M.J., LI, Y.F., WANIA, F., ALAEE, M., ALEXEEVA, L.B., BACKUS, S.M., BAILEY, R., BEWERS, J.M., GOBEIL, C., HALSALL, C.J., HARNER, T., HOFF, J.T., JANTUNEN, L.M.M., LOCKHART, W.L., MACKAY, D., MUIR, D.C.G., PUDYKIEWICZ, J., REIMER, K.J., SMITH,
J.N., STERN, G.A., SCHROEDER, W.H., WAGEMANN, R., and YUNKER, M.B. 2000. Contamination in the Canadian Arctic: 5 years of progress in understanding sources, occurrence and pathways. The Science of the Total Environment 254:93-234.

MICHENER, R.H., and SCHELL, D.M. 1994. Stable isotope tracers in marine aquatic food webs. In: Lajtha, K., and Michener, R.H., eds. Stable isotopes in ecology and environmental science. London: Blackwell Scientific. 138-157.

NIXON, M.F. 2000. Thaw depth monitoring. In: Dyke, L.D., and Brooks, G.R., eds. The physical environment of the Mackenzie Valley, Northwest Territories: A base line for the assessment of environmental change. Geological Survey of Canada Bulletin 547. $106-114$.

NRIAGU, J.O. 1989. A global assessment of natural sources of atmospheric trace metals. Nature 338:47-49.

OUTRIDGE, P.M., EVANS, R.D., WAGEMANN, R., and STEWART, R.E.A. 1997. Historical trends of heavy metals and stable lead isotopes in beluga (Delphinapterus leucas) and walrus (Odobenus rosmarus rosmarus) in the Canadian Arctic. The Science of the Total Environment 203:209-219.

OUTRIDGE, P.M., WAGEMANN, R., and McNEELY, R. 2000a. Teeth as biomonitors of soft tissue mercury concentrations in beluga, Delphinapterus leucas. Environmental Toxicology and Chemistry 19:1517-1522.

OUTRIDGE, P.M., McNEELY, R., and DYKE, A.S. 2000b. Historical trends of stable lead isotopes, mercury and other trace metals in marine bivalve shells from the Canadian Arctic. In: Nriagu, J., ed. Proceedings of the 11th International Conference on Heavy Metals in the Environment, 6-10 August 2000, Ann Arbor, Michigan. Contribution No. 1179. (CD-ROM).

OUTRIDGE, P.M., HERMANSON, M.H., and LOCKHART, W.L. In press. Regional variations in atmosphere deposition and sources of anthropogenic lead in lake sediments across the Canadian Arctic. Geochimica et Cosmochimica Acta.

PAINTER, S., CAMERON, E.M., and ALLEN, R. 1994. Reconnaissance geochemistry and its environmental significance. Journal of Geochemical Exploration 51:213-246.

ROGNERUD, S., SKOTVOLD, T. FJELD, E., NORTON, S.A., and HOB EK, A. 1998. Concentrations of trace metals in recent and preindustrial sediments from Norwegian and Russian Arctic lakes. Canadian Journal of Fisheries and Aquatic Sciences 55:1512-1523.

SCHELL, D.M. 2000. Declining carrying capacity in the Bering Sea: Isotopic evidence from whale baleen. Limnology and Oceanography 45:459-462.

SIEGEL, F.R., GALASSO, J.J., and KRAVITZ, J.H. 2001. Geochemistry of thirteen Voronin Tough cores, Kara Sea, European Arctic: $\mathrm{Hg}$ and As contaminants at a 1965 timeline. Applied Geochemistry 16:19-34.

SOKAL, R.R., and ROHLF, F.J. 1981. Biometry. 2nd ed. New York: Freeman \& Co.

STURGES, W.T., HOPPER, J.F., BARRIE, L.A., and SCHNELL, R.C. 1993. Stable lead isotope ratios in Alaskan Arctic aerosols. Atmospheric Environment 27A:2865-2871.

USSR. 1967. Metallogenic map of the U.S.S.R., 1967 (In Russian). Scale: 1:750 000. Moscow: U.S.S.R. Ministry of Geology. 2 Sheets. 
WAGEMANN, R., and STEWART, R.E.A. 1994. Concentration of heavy metals and selenium in tissues and some foods of walrus (Odobenus rosmarus rosmarus) from the eastern Canadian Arctic and Sub-Arctic, and associations between metals, age and gender. Canadian Journal of Fisheries and Aquatic Science 51:426-436.

WAGEMANN, R., LOCKHART, W.L., WELCH, H., and INNES, S. 1995. Arctic marine mammals as integrators and indicators of mercury in the Arctic. Water, Air and Soil Pollution 80: $683-693$.
WAGEMANN, R., INNES, S., and RICHARD, P.R. 1996. Overview and regional and temporal differences of heavy metals in Arctic whales and ringed seals in the Canadian Arctic. The Science of the Total Environment 186:41-66.

WHEATLEY, B., and WHEATLEY, M. 1988. Methylmercury in the Canadian Arctic environment past and present-natural or industrial? Arctic Medical Research 47(Supplement 1): $163-167$. 